\title{
Analisis Pendapatan Budidaya Ikan Nila di Kelompok Tani Mandiri Desa Popnam Kecamatan Noemuti
}

\author{
Oktovianus Neno ${ }^{\mathrm{a}}$, Yosefina Marice Fallo ${ }^{\mathrm{b}}$, dan Marsianus Falo ${ }^{\mathrm{c}}$ \\ ${ }^{a}$ Fakultas Pertanian, Universitas Timor, Kefamenanu, TTU - NTT, Indonesia. \\ ${ }^{b}$ Fakultas Pertanian, Universitas Timor, Kefamenanu, TTU - NTT, Indonesia. \\ ${ }^{c}$ Fakultas Pertanian, Universitas Timor, Kefamenanu, TTU - NTT, Indonesia.
}

\section{Article Info}

\section{Article history:}

Received 8 Juli 2016

Received in revised form 23 Juli 2016

Accepted 25 Juli 2016

\section{Keywords:}

Pendapatan

Keuntungan Relatif

Ikan Nila

Popnam

Noemut

\begin{abstract}
Abstrak
Penelitian ini bertujuan untuk mengetahui gambaran budidaya ikan Nila, besarnya pendapatan petani yang diperoleh dari budidaya ikan Nila, dan keuntungan relatif dari budidaya ikan Nila di Kelompok Tani Mandiri Desa Popnam Kecamatan Noemuti Kabupaten Timor Tengah Utara. Metode pengambilan sampel dilakukan dengan metode sensus sebanyak 25 orang pada kelompok tani Mandiri, metode pengumpulan data dilakukan dengan metode survey, data yang diambil berupa data primer dan sekunder, sedangkan metode analisis data yang digunakan adalah metode analisis data deskripsi kualitatif, metode analisis pendapatan dan metode analisis keuntungan relatif. Hasil penelitian menyimpulkan bahwa pembudidayaan ikan Nila dilalui 4 tahap dan tahap awal atau pertama yaitu persiapan kolam dan kegiatan persiapan kolam terdiri dari 2 kegiatan besar yaitu mengeringkan kolam kemudian kolam dijemur sampai tanah terlihat retak dan mengisi air pada kolam lalu dibiarkan terkena sinar matahari, tahap yang kedua penebaran benih yang mana umur benih ikan Nila, selanjutnya adalah pemeliharaan kolam dan ikan Nila, pemeliharaan kolam dilakukan dengan memungut sampah yang jatuh di atas kolam dan pemeliharaan ikan dilakukan dengan pemberian pakan ikan secara rutin dua kali sehari dan tahap terakhir yaitu panen dan pasca panen dilakukan setelah melewati masa pemeliharaan selama 4 bulan. Perolehan pendapatan dari anggota kelompok tani berkisar antara $\mathrm{Rp}$. 2.051.741,-- sampai Rp. 5.803.695,- dengan rata-rata pendapatan dari satu kali produksi budidaya ikan Nila sebesar Rp. 3.082.665,sedangkan total pendapatan anggota kelompok tani dalam satu kali produksi budidaya ikan Nila Rp. $77.066 .633,-$. Keuntungan relatif dar anggota kelompok tani berkisar antara 2 sampai 4 dan rata-rata keuntungan relatif dari anggota kelompok tani adalah 3 sehingga bisa dikatakan bahwa budidaya ikan Nila yang di lakukan oleh anggota kelompok tani secara ekonomis menguntungkan sebab hasil perhitungan keuntungan relatif dari anggota kelompok tani lebih dari 1 (>1). (22016 dipublikasikan oleh Agrimor.
\end{abstract}

\section{Pendahuluan}

Indonesia merupakan salah satu negara kepulauan terbesar di dunia terdir dari gugusan pulau-pulau sebanyak 17.508 dengan luas perairan laut Indonesia diperkirakan sebesar 5,8 juta $\mathrm{km}^{2}$ dan panjang garis pantai $95.181 \mathrm{~km}$, keadaan yang demikian menyebabkan Indonesia memiliki potensi yang cukup besar di bidang perikanan, mulai dari prospek pasar baik dalam negeri maupun internasional. Oleh karena itu, potensi Sumber Daya Alam baik yang di laut maupun di wilayah pesisir, sangat berpeluang besar dalam usaha pengembangan dan pemanfaatannya (Sudirman dan Karim, 2008).

Produk perikanan budidaya yang bebas residu atau di bawah ambang batas residu yang diperbolehkan sesuai dengan permintaan pasar dengan perolehan persentase produk perikanan budidaya yang bebas residu yaitu sebesar $99,73 \%$. Sasaran lokasi uji residu adalah sentra produksi perikanan budidaya di 17 provinsi dengan komoditas udang, Nila, bandeng dan lele (RENSTRA DJPB 2015-2019).

Ikan Nila merupakan hewan yang hidup di air yang menjadi salah satu dari sekian banyak bahan makanan yang dibutuhkan manusia, ikan sangat bermanfaat bagi manusia sebab di dalamnya terdapat bermacam zat-zat yang dibutuhkan oleh tubuh manusia seperti : protein, vitamin, dan mineral. Selain itu apabila dibandingkan dengan sumber penghasil protein lain seperti daging, susu, dan telur harga ikan relatif paling murah dijangkau oleh masyarakat, sebagai sumber protein ada komposisi yang terkandung dalam ikan Nila komposisi tersebut adalah komposisi kimia dan komposisi kimia ikan Nila per 100 gram daging dapat menunjukkan bahwa ikan Nila memiliki kandungan lemak yang cukup rendah $(2,7 \%)$ dan kandungan protein yang cukup tinggi $(17,8 \%)$ (Kusumawardhani,1988).

Berdasarkan data statistik Kecamatan Noemuti produksi ikan Nila pada tahun 2010 produksi ikan Nila mencapai 1,3 ton, tahun 2011 produksi ikan Nila mencapai 1,2 ton, tahun 2012 produksi ikan Nila mencapai 1,3 ton, tahun 2013 produksi ikan Nila mencapai 1,10 ton, dan tahun 2014 produksi ikan Nila mencapai 1,20 ton. (Noemuti dalam Angka, 2014). Hal ini menunjukkan bahwa peluang usaha budidaya ikan Nila terbuka bagi petani ikan, oleh karena itu perlu dilakukan suatu kajian dengan topik Analisis Pendapatan Budidaya Ikan Nila di Kelompok Tani Mandiri Desa Popnam Kecamatan Noemuti Kabupaten Timor Tengah Utara dengan tujuan untuk mengetahui gambaran budidaya ikan Nila, mengetahui besarnya pendapatan petani yang diperoleh dari budidaya ikan Nila, dan mengetahui keuntungan relatif dari budidaya ikan Nila di Kelompok Tani Mandiri Desa Popnam Kecamatan Noemuti Kabupaten Timor Tengah Utara (TTU).

\section{Metode}

Penelitian ini dilaksanakan di Kelompok Tani Mandiri Desa Popnam Kecamatan Noemuti pada bulan November 2015 sampai Juli 2016 terhitung sejak pengambilan data awal dilapangan. Pengambilan sampel dilakukan dengan metode sensus, yang mana seluruh anggota Kelompok Tani Mandiri dijadikan sebagai responden sebanyak 25 orang. Pengumpulan data dilakukan dengan metode survei, dimana data yang dikumpulkan berupa data primer dan data sekunder. Data primer adalah data yang diperoleh langsung dari responden melalui wawancara berdasarkan daftar pertanyaan yang disiapkan sebelumnya, sedangkan data sekunder adalah data yang diperoleh dari instansi terkait data yang dikumpulkan dianalisis dengan menggunakan analisis deskripsi kualitatif dan analisis pendapatan menurut petunjuk Soekartawi (1993) serta analisis keuntungan relatif (R/C Ratio) sesuai petunjuk Tjakrawiralaksana dan Soeariatmadja (1983).

\section{Hasil dan Pembahasan \\ 3.1 Gambaran Budidaya Ikan Nila}

- Persiapan Kolam

Persiapan kolam yang dilakukan oleh petani budidaya ikan Nila dengan mengeringkan kolam, penjemuran, mengali, pemupukan, dan pengisian air dan dengan luas lahan yang digunakan untuk pembuatan kolam bervariasi mulai dari 0,24 are sampai yang luas lahan 10 are dengan ukuran kolamnya juga bervariasi mulai dari ukuran $4 \mathrm{~m}$ X $6 \mathrm{~m}$ sampai $6 \mathrm{~m}$ X $8 \mathrm{~m}$.

Pengeringan kolam dilakukan secara tradisional tanpa menggunakan teknologi dengan menguras kolam atau mengeluarkan semua air dari dalam kolam, setelah itu kolam di jemur dengan menggunakan tenaga matahari. Penjemuran kolam berlangsung selama $4-7$ hari tergantung pada cuaca. Namun sebagai patokan kolam yang dijemur sudah cukup bila permukaan tanah terlihat retak, namun tidak sampai membatu dan jika diinjak masih meninggalkan jejak kaki.

Kolam ikan yang sudah dijemur selanjutnya di gali menggunakan linggis, dengan tenaga manusia yang sumber tenaga kerjanya berasal dari dalam keluarga dan jika pun dari luar keluarga merupakan tenaga sukarela. Kolam digali sampai kedalaman tertentu atau sebagai patokan kolam digali dengan tujuan membersihkan dasar kolam dari sampah-sampah, kerikil-kerikil terutama dari lumpur hitam berbau amis yang berasal dari sisa-sisa pakan yang tidak habis.

Selanjutnya kolam diberi pupuk dan pupuk yang diberikan pupuk organik dan pupuk anorganik, pupuk kandang berupa pupuk kadang yang berasal dari kotoran sapi dan pupuk anorganik atau pupuk kimia yang digunakan adalah pupuk urea. Volume pupuk yang diberikan tergantung pada besaran kolam yang dibuat oleh petani yang mana pupuk digunakan untuk merangsang pertumbuhan tanaman yang berfungsi sebagai tempat tinggal ikan, selain itu pupuk juga digunakan sebagai perangsang adanya senyawa lainnya yang nantinya bisa dijadikan sebagai pakan ikan Nila nantinya.

Persiapan kolam yang terakhir adalah pengisian air pada kolam ikan yang sudah dibersihkan dan di beri pupuk, air diisi dengan ketinggian $50 \mathrm{~cm}$ sampai 1 $\mathrm{m}$, sesuai ketinggian kolam yang di gunakan dan rata-rata ketinggian kolam, yang digunakan untuk budidaya ikan Nila.

- Penebaran Benih

Setelah kolam diisi dengan air maka didiamkan selama $5-7$ hari dengan maksud agar cahaya matahari dapat menembus ke dalam air untuk proses pertumbuhan tumbuhan dan senyawa lain dalam kolam untuk pakan ikan Nila nantinya.

Benih ikan Nila kemudian ditebar ke dalam kolam dengan jumlah berdasarkan ukuran kolam dan banyaknya benih ikan Nila yang ditebarkan berkisar antara 750 - 1.500 ekor. Benih ikan Nila yang sudah dianggap layak sebagai benih jika ikan Nila sudah berumur \pm 2 minggu.

- Pemeliharaan Ikan dan Kolam

Metode pemeliharaan ikan dan kolam yang di lakukan oleh anggota kelompok tani, dengan membersihkan kolam, setiap harinya, pembersihan kolam yang dimaksud adalah dengan memungut daun-daun kering yang jatuh ke atas kolam atau sampah lainnya.

Pemeliharaan ikan dilakukan dengan memperhatikan pakan ikan yang diberikan secara rutin oleh petani dengan frekuensi pemberian 2 kali dalam sehari yaitu pagi dan sore. Jenis pakan ikan yang diberikan yaitu pellet ikan yang diperoleh petani dari toko pertanian dan cara perolehannya dengan mengeluarkan biaya untuk pembelian pakan ikan yaitu pellet ikan. Selain pellet petani juga menggunakan ampas kelapa sebagai pakan substitusi yang mana ampas kelapa diberikan seminggu sekali atau jika ampas tersedia. 
Pada siang hari ikan biasanya makan dari tumbuhan dan senyawa lain yang hidup dalam air seperti cacing, jentik-jentik nyamuk, maupun siput. Pemeliharaan ikan dilakukan selama 4 bulan sebelum masuk masa panenan ikan Nila.

- Panen dan Pasca Panen

Memasuki masa panen ikan petani mempersiapkan alat yang diperlukan seperti serok untuk menjaring ikan, dan panen dilakukan saat ikan sudah berumur 4 bulan masa pemeliharaan.

Pasca panen petani melakukan sortir yang mana ikan Nila yang dianggap layak dijual dan ikan Nila yang dianggap belum layak dan sebagai patokan ikan Nila yang dianggap dijual adalah ikan yang sehat dan segar hal ini dibuktikan dengan warna sisik dan mata yang cerah.

\subsection{Pendapatan Budidaya Ikan Nila}

Pendapatan budidaya ikan Nila adalah selisih antara penerimaan dari budidaya ikan Nila dengan semua biaya dalam budidaya ikan Nila.

\section{a. Biaya Budidaya Ikan Nila}

Biaya budidaya ikan Nila yang di keluarkan selama 1 (satu) periode budidaya yang mana petani mengeluarkan segala jenis biaya baik itu biaya tetap maupun biaya variabel dalam bentuk uang, dan juga dalam bentuk barang yang di konversikan ke dalam bentuk uang dalam kurs rupiah (Rp).

Biaya variabel yang digunakan dalam 1 (satu) periode budidaya ikan Nila terdiri dari, biaya bibit ikan Nila biaya pupuk, biaya pakan ikan Nila dan biaya transportasi. Total biaya variabel yang dikeluarkan dalam 1 (satu) periode budidaya ikan Nila dari anggota kelompok tani budidaya ikan Nila sebesar Rp. 42.448.000,- dengan rata-rata biaya variabel sebesar Rp. 1.697.920,-

Biaya tetap yang dihitung dalam penelitian ini adalah biaya penyusutan alat yang digunakan dalam budidaya ikan Nila, sebab alat yang digunakan sampai saat ini masih terus digunakan oleh anggota kelompok tani yang membudidayakan ikan Nila. Alat yang digunakan seperti pacul, linggis, parang, ember, sekop, serok, waring dan pipa paralon.

Biaya penyusutan dihitung setiap bulannya sesuai dengan umur ekonomis dengan menggunakan Nilai residu atau harga akhir dari alat sehingga rata-rata biaya penyusutan alat setiap bulannya sebesar Rp. 239.415sedangkan total biaya penyusutan ke delapan alat yang digunakan oleh anggota kelompok tani budidaya ikan Nila sebesar Rp. 5.985.367.

\section{b. Penerimaan Budidaya Ikan Nila}

Penerimaan merupakan jumlah uang yang diperoleh dari penjualan sejumlah hasil produksi yang dihasilkan, dalam penelitian ini penerimaan di lihat dari harga jual dikalikan dengan total produksi dalam 1 kali produksi yang kemudian diperoleh penerimaan.

Harga jual yang dihitung dalam penelitian ini adalah harga jual per kilogram ikan yang terdiri dari 8 ekor ikan Nila yang berumur 3-4 bulan, harga yang ditawarkan oleh para petani budidaya ikan Nila sebesar Rp. 50.000,-

Hasil produksi selama 1 periode budidaya ikan Nila tergantung dari jumlah bibit ikan yang dibudidaya, jumlah bibit yang di budidaya berkisar antara 750 ekor sampai 1.500 ekor bibit ikan Nila dan total bibit yang di budidayakan oleh anggota kelompok tani budidaya ikan Nila sebesar 25.300 ekor. Sedangkan besarnya lahan yang dijadikan kolam oleh petani budidaya ikan Nila berkisar antara 0,24 are sampai 10 are dengan total keseluruhan luas lahan yang digunakan untuk budidaya ikan Nila dari anggota kelompok tani ikan Nila sebesar 66.92 are sehingga hasil produksi bervariasi mulai dari $79 \mathrm{~kg}$ sampai 161 $\mathrm{kg}$ dari total produksi untuk anggota kelompok tani budidaya ikan Nila sebesar $2.510 \mathrm{~kg}$

Harga yang ditawarkan sebesar Rp. 50.000 kemudian dikalikan dengan total produksi ikan Nila dari anggota kelompok tani ikan Nila sebesar $2.510 \mathrm{~kg}$, maka penerimaan yang diterima oleh anggota kelompok tani ikan Nila rata-rata Rp. 5.020.000 dan total penerimaan anggota kelompok tani ikan Nila sebesar Rp. 125.500.000,-

\section{c. Pendapatan}

Pendapatan merupakan hasil penjualan bersih yang diterima oleh petani dalam usahatani, pendapatan juga merupakan selisih antara penerimaan dan total biaya produksi baik itu biaya variabel maupun biaya tetap. Pendapatan dalam penelitian ini merupakan hasil budidaya ikan Nila yang di jual yang kemudian disebut dengan penerimaan yang dikurangi dengan total biaya yang terdiri dari biaya variabel dan penyusutan peralatan dalam 1 kali produksi budidaya ikan Nila.

Perolehan pendapatan dari anggota kelompok tani berkisar antara Rp. 2.051.746,- sampai Rp. 5.803.695,- dengan rata-rata pendapatan dari satu kali produksi budidaya ikan Nila sebesar Rp. 3.082.665,- sedangkan total pendapatan anggota kelompok tani dalam satu kali produksi budidaya ikan Nila Rp. 77.066.633,-

\subsection{Kelayakan Budidaya Ikan Nila}

Kelayakan budidaya ikan Nila di lokasi penelitian dianalisis menggunakan analisis return cost ratio $(\mathrm{R} / \mathrm{C})$, yaitu perbandingan antara penerimaan total dengan biaya total.

Ketentuan bahwa jika hasil pembagian total penerimaan dengan total biaya kurang dari satu $(<1)$ secara ekonomis budidaya ikan Nila tidak menguntungkan, jika hasil pembagian total penerimaan dengan total biaya sama dengan satu $(=1)$ secara ekonomis budidaya ikan Nila tidak menguntungkan dan tidak merugikan, jika hasil pembagian total penerimaan dengan total biaya lebih dari satu (>1) secara ekonomis budidaya ikan Nila menguntungkan.

Berdasarkan perhitungan diperoleh rentang keuntungan relatif dari anggota kelompok tani berkisar antara 2 sampai 4 dan rata-rata keuntungan relatif dari anggota kelompok tani adalah 3 sehingga bisa dikatakan bahwa budidaya ikan Nila yang di lakukan oleh anggota kelompok tani secara ekonomis menguntungkan sebab hasil perhitungan keuntungan relatif dari anggota kelompok tani lebih dari 1 (> 1).

\section{Simpulan}

Pembudidayaan ikan Nila dilalui 4 tahap dan tahap awal atau pertama yaitu persiapan kolam dan kegiatan persiapan kolam terdiri dari 2 kegiatan besar yaitu mengeringkan kolam kemudian kolam dijemur sampai tanah terlihat retak dan mengisi air pada kolam lalu dibiarkan terkena sinar matahari selama \pm 7 hari, tahap yang kedua penebaran benih yang mana umur benih ikan Nila yang ditebar \pm 2 minggu (14 hari) lalu di masukan ke dalam kolam dan jumlah benih diisi dalam kolam sesuai dengan ukuran kolam, selanjutnya adalah pemeliharaan kolam dan ikan Nila, pemeliharaan kolam dilakukan dengan memungut sampah yang jatuh di atas kolam dan pemeliharaan ikan dilakukan dengan pemberian pakan ikan secara rutin dua kali sehari dan tahap terakhir yaitu panen dan pasca panen dilakukan setelah melewati masa pemeliharaan selama 4 bulan yang mana alat yang digunakan adalah serok dan cara penanganan yaitu ikan dijaring, dan setelah itu ikan Nila disortir untuk kemudian dijual kepada konsumen maupun pedagang yang mendatangi lokasi pembudidayaan ikan Nila. Perolehan pendapatan dari anggota kelompok tani berkisar antara Rp. 2.051.741,- sampai Rp. 5.803.695,- dengan rata-rata pendapatan dari satu kali produksi budidaya ikan Nila sebesar Rp. 3.082.665,- sedangkan total pendapatan anggota kelompok tani dalam satu kali produksi budidaya ikan Nila Rp. 77.066.633,-. Keuntungan relatif dari anggota kelompok tani berkisar antara 2 sampai 4 dan rata-rata keuntungan relatif dari anggota kelompok tani adalah 3 sehingga bisa dikatakan bahwa budidaya ikan Nila yang di lakukan oleh anggota kelompok tani secara ekonomis menguntungkan sebab hasil perhitungan keuntungan relatif dari anggota kelompok tani lebih dari $1(>1)$

\section{Pustaka}

Direktorat Jenderal Perikanan Budidaya. 2015 . Peraturan Direktur Jenderal Perikanan Budidaya Nomor 113/PER-DJPB/2015 Tentang Rencana Strategis Direktorat Jenderal Perikanan Budidaya Tahun 2015 - 2019. [Internet] Diakses : 13 Mai 2016.

Noemuti dalam Angka 2014. Data Produksi Ikan Nila. Kecamatan NoemutiTTU. Kefamenanu.

Kusumawardhani, D. R. 1988. Studi Proses Pembuatan Pakan Protein Ikan dari Ikan Bandeng (Chanos chanos) dan Ikan Nila Merah (Oreochromis sp) dalam Berbagai Pengolahan dengan Menggunakan Spray Dryer. Skripsi. Fakultas Perikanan. Institut Pertanian Bogor. Bogor

Soekartawi, 1993. Analisis Usahatani. Jakarta: Universitas Indonesia.

Sudirman, H dan M. Yusri Karim. 2008. Ikan Kerapu (Biologi Eksploitasi Manajemen dan Budidayanya). Yasrif Watampone. Jakarta.

Tjakrawiralaksana, A dan C. Soeriaatmadja. 1983. Usahatani. Jakarta: Departemen Pendidikan dan Kebudayaan. 